\title{
Speleology: rock-climbing and geomorphologic approach
}

\section{Espeleología: escalada y enfoque geomorfológico}

DOI: $10.46932 /$ sfjdv2n5-039

Received in: Jun 1st, 2021

Accepted in: Sep 30th, 2021

\author{
Anatoliy Bulychov \\ $\mathrm{PhD}$ \\ Institute of Geology and Mineralogy SB RAS, Koptyug av.,3 Novosibirsk, 630090 Russia, \\ E-mail: bull@ngs.ru
}

\begin{abstract}
Since 1975 the Club of cavers based at Novosibirsk State University has performed an extra-ordinary method of caver training. Serious rock-climbing preparation and technical mountaineering with a background of intensive physical coaching have resulted in the discovery of large cave systems on the Altai and Sayan ranges.

Overcoming high walls up inside the caves using free climbing and the use of aid techniques from alpinism was mandatory. Mountaineering skills allowed us to investigate plateaus on high altitudes on Zeravshanskiy (Mount Patroush) and Gissarskiy (Mount Hodja-Ahcha-Baroun) ranges, as well as pseudo karst in the vicinity of Khan-Tengri, Kilimanjaro, Aconcagua peaks, combined with geological surveying and prospecting.

For all times the philosophical aspects of fair play in sports was an inherent part in our activity.

The digital presentation of underground mapping and structures monitoring on surface made possible to discover a tectonic-geomorphologic speleogenesis of conglomerate caves of the Narva's suite (Siberia, Manskiy trough). The most outstanding caves of the massif are Big Oreshnaya and Badjeiskaya, and unique as their length is about $50 \mathrm{~km}$ and $10 \mathrm{~km}$ respectively, while in general, there is no significant development of caves in such rocks in the world. Our geomorphologic observations show the presence of large linear faults, which played an obvious role in karstogenesis, and the presence of signs of near-surface cave levels, which have not been discovered yet.
\end{abstract}

Keywords: caving, alpine-climbing, training, sport, mountaineering, digital mapping, structural analysis, geomorphology, speleogenesis.

\section{RESUMEN}

Desde 1975, el Club de espeleólogos con sede en la Universidad Estatal de Novosibirsk ha llevado a cabo un método extraordinario de formación de espeleólogos. Una seria preparación de escalada en roca y montañismo técnico con un fondo de entrenamiento físico intensivo han dado como resultado el descubrimiento de grandes sistemas de cuevas en las cordilleras de Altai y Sayan.

La superación de altas paredes en el interior de las cuevas mediante la escalada libre y el uso de técnicas de ayuda del alpinismo era obligatoria. Los conocimientos de alpinismo nos permitieron investigar las mesetas de gran altura en las cordilleras Zeravshanskiy (Monte Patroush) y Gissarskiy (Monte HodjaAhcha-Baroun), así como el pseudokarst en las cercanías de los picos Khan-Tengri, Kilimanjaro, Aconcagua, combinados con la topografía y la prospección geológica.

En todo momento los aspectos filosóficos del juego limpio en el deporte fueron parte inherente a nuestra actividad.

La presentación digital de la cartografía subterránea y el seguimiento de las estructuras en la superficie permitieron descubrir una espeleogénesis tectónica-geomorfológica de las cuevas de conglomerado del 
conjunto de Narva (Siberia, la depresión Manskiy). Las cuevas más destacadas del macizo son Big Oreshnaya y Badjeiskaya, y únicas ya que su longitud es de unos $50 \mathrm{~km}$ y $10 \mathrm{~km}$ respectivamente, mientras que, en general, no hay un desarrollo significativo de cuevas en tales rocas en el mundo. Nuestras observaciones geomorfológicas muestran la presencia de grandes fallas lineales, que desempeñaron un papel evidente en la karstogénesis, y la presencia de indicios de niveles de cuevas cercanos a la superficie, que aún no han sido descubiertos.

Palabras clave: espeleología, alpinismo, entrenamiento, deporte, montañismo, cartografía digital, análisis estructural, geomorfología, espeleogénesis.

\section{ROCK-CLIMBING APPROACH}

\subsection{INTRODUCTION}

Caving is a complicated multi-faceted sport, so one has to remember all aspects of preparation. There are several directions of training.

1. General physical preparation: any exercise (cross-country race, skiing, gymnastic) to increase our health, endurance, stamina, strength of muscles is acceptable.

2. Technical preparation: comprising working with equipment, ropes and steel cables, belaying, rescue operations.

3. Psychology: including personal, moral and strong-willed preparation, ability to work in a group, stress management, conflict resolution, and an ability to recognize one's own mistakes.

4. Cognitive knowledge which unifies all theoretical information about contemporary equipment, tactics and strategy, physics of belaying, and of course, a general geology about caves and mountain formation. 5. Special physical preparation. This is a training of climbing on different types of relief. Initially it may be possible to use a climbing gym but the main aim must be an outdoor experience.

The qualifications of a caver are determined not by the best what one can do under the points above but the opposite, by the weakest application of one's skills. Although we were already strong cavers with experience in Sneznaya cave (-1370m, Caucasus) many of us found that climbing was our weakest skill. That is why it appeared to be best to improve our climbing abilities.

\section{COMPARATIVE EXPERIMENT}

An experimental hypothesis was proposed to prove that rock-climbing training would increase the efficiency of overcoming of challenging routes in caves. The criteria of efficiency were necessary to define, i.e. data by what was possible to judge which group or individual was better. Caving is a sport involving parties of 2 or 4 participants; parties are a big expedition comprises several such parties. Therefore, two groups of 4 people were compared in a number of caves on similar challenging routes. 
The first group was a basic (traditional) one who had not used climbing training. The second group was experimental one who persistently trained in rock-climbing. The criteria of an experiment were time and quality of overcoming of a route. The tasks proceeded were as follows.

1. The investigation topic (object); the preparation of sportsmen-cavers.

General (traditional) training of a caver is widely discussed in text-books (Дублянский, Илюхин, 1981) where there is a common training process for classic routes to get the bottom of the cave and to escape to the surface along prior fixed ropes. Climbing in caves is mostly limited by easy chimney scrambling. Nevertheless a feature of caves in Siberia consists in a necessity of a lot of free climbing in ordinary routes. One of our best training grounds is Torgashinskaya cave situated near the border of Krasnoyarsk city. There are many various challenging routes; as described herewith. A sequence of precipices 40, 30, $20 \mathrm{~m}$ interrupted by a short labyrinth, $20 \mathrm{~m}$ chimney up, and $40 \mathrm{~m}$ traverse of a fault. The cave continues with two 20 and 40m precipices to get the bottom of the cave. To continue the route demands not to use the fixed ropes (usually we remove all of them). The group has then to free climb up a 10m wall to enter the vertical labyrinth system of up-going wells where there are a lot of free climbs (up to 6b+ French category, 5.10d USA). This ascent is a way to the surface instead of rope climbing ("jumaring"). What are the results of the experiment? In terms of quality the traditional group (T) has to have at least one good rock-climber who is able to lead on French 6-th categories (5.10), otherwise the group may be stranded at the bottom because the fixed ropes have been removed. If the group has such a climber he leads and organizes fixed ropes for all other participants up a long multi pitch ascent. In case of the experimental group of climbers $(\mathrm{C})$ they ascend in independent two parties of two people in each; all participants free climb and use no fixed ropes. It looks like a beautiful and glorious alpine climb. In terms of time, without previous rehearsals ("on-site") group $\mathrm{C}$ overcomes the route twice as fast as group $\mathrm{T}$. Subsequent replays only increase a gap of time spent, irrespective of climbing quality.

2. Climbing training (subject) for preparing cavers for challenging caves.

What is the training process we follow? On the one hand it is a typical routine (Пиратинский, 1987), i.e. persistent repeated coaching until a climber is noticed to rest to a set limit and can't guess how to make a breakthrough. So, on the other hand our honor is to direct the climber for the sake of success and consequently, pleasure. Climbers overcome long multi-pitches routes in caves or mountains, thus our advice is appropriate to the specific technique (Ситник, 2016).

Firstly, all accidental falls from height are excluded during a lead and this eliminates two reasons of falls: a) climber finding himself on a pitch that he had underestimated before; our observations resulted in 2 pieces of advise: to climb more with top belay up to $50 \mathrm{~m}$ on rocks to learn to orientate oneself on relief and to lead pitches that are at least 1 category easier than one's upper level; 
b) muscles of hands and feet (mainly, calf) are haggard and may be seized with cramp; the advise is to avert it by smoothed composed deliberate climbing in an aerobic regime; for this a special climbing technique is proposed and used as follows.

-Climb mainly with the use of feet. Position of the body is vertical or slightly leaned back to increase a normal pressure on the rock making better friction.

-Optimal position of legs - one is straight, another is lifted up and bent in the knee. Don't lift high the heels for long as the calf may exhaust and suffer from a cramp.

-Climb without strain; stress only muscles that are necessary for that move.

-Use twists instead of pulls up, revolving a body around a loaded forearm, turning a leg into inside and transforming a body position to layback one.

-On a cornice hold the pelvis closer to the rock and try to use laybacks more.

-Climb with straight arms and hold them raised as less as possible. Optimal position is with straight arms at heart level. If holds are high then move feet higher quickly.

-Chimney scrambling, laybacks, "stem"-climbing are preferable when possible. It is opposing pressures on sidewalls that increase friction on the rock.

-To decrease stress of muscles of the arm when taking a hold above, make by the other arm an opposing pressure on the hold lower down (technique of "third leg").

-In order to set up protection, dispose legs on opposing sidewalls supporting a balance. Often it's necessary to lift one leg higher in layback to get an opportunity to move the free arm very high up to insert a cam or nut.

-Concentrate will-power and thoughts before a crux. After the crux dispose the body on ledges to decrease stress shaking hands by turns. Follow smooth breathing.

To develop endurance and stamina, the regular cross-country skiing (or running) races are undertaken all year round (Bulychov, Sorokina, 2013).

3. Changes in subject during experiment were carried out.

Instead of limitless climbs with top belay, a method working out special technical elements was offered. To develop the ability to not be afraid of falls during leading, it was believed to climb 1-2 categories of difficulty lower routes than one's top belay level. However, special trainings of premeditated falls were worked out for same categories of either top or leading belay (Todhunter, 1998). It develops confidence and trust in the elements of protection set by a climber.

4. Expertise of efficiency and inferences.

This experiment was further undertaken in a number of well-known caves such as Napra (-970m, Caucasus), Kievskaya (-980m, Kyrk-Tau), Kek-Tash (-350m, Altai) (Boulytchov, 1999), Altaiskaya (- 
240m, Altai). The result was found to be the same everywhere - time spent to overcome equal segments by a group $\mathrm{C}$ was about twice as fast as that by a group $\mathrm{T}$. Participants in all groups were different in every cave noted.

Most remarkable was a sporty route offered in the cave Big Oreshnaya (Boulytchov, 1999) ( $\mathrm{A}=234 \mathrm{~m}, \mathrm{~L}=47700 \mathrm{~m}$, East Sayan) and due to our free climbing abilities, the 70-m sheer wall (6b French, 5.10c) was overcome (first ascent). On the upper part of the wall we stumbled upon extreme narrow squeeze that led to a new huge system, Sibirskaya. Later in the lowest part of this system a connection with main cave was dug by V.Sherbakov, so a challenging circle to overcome might be tried. Another circle was the traverse of the Lake: a $20 \mathrm{~m}$ chimney and $10 \mathrm{~m}$ face $(5 \mathrm{c}, 5.9)$ led down to the lake; a $20 \mathrm{~m}$ face $(6 \mathrm{~b}, 5.10 \mathrm{c})$ traverse above water followed; a traverse $20 \mathrm{~m}$ above a precipice and $5 \mathrm{~m}$ face up $(6 \mathrm{a}$, $5.10 \mathrm{~b})$ led to a wide $20 \mathrm{~m}$ tube (in shape of bottle with neck from the top) mandatory to climb up (6b+, 5.10d). This tube began with exclusively hard $5 \mathrm{~m}$ full-body stretch and continued with wide chimney climbing up all upper part. Big Oreshnaya cave represents a huge intricate labyrinth so in the maze the way was properly marked to set groups in equal conditions so they did not loose time seeking the correct route in non technical areas. In the experiment 20 different groups $\mathrm{C}$ and $\mathrm{T}$ took part for 10 years. The group $\mathrm{C}$ worked during the ascents in independent 2 parties of 2 people; all participants free climbed. In the group $\mathrm{T}$ the first climber led, all other 3 participants used fixed ropes and appropriate gear; the traverse along the lake was avoided and substituted with the use of a dinghy. Average time spent by groups $\mathrm{C}$ for all route occurred about 3 times less than appropriate one of groups T. One drawback of the climbing style is that it demands use of an alpine sit-harness since the speleo one isn't convenient for leading on ascents. Another drawback is that cave-climbers almost always transform to alpine-climbers and change their passion to mountains. 
Fig.1 Altaiskaya cave (mapped by A. Bulychov), L=4740m, -240m, on 2016 year

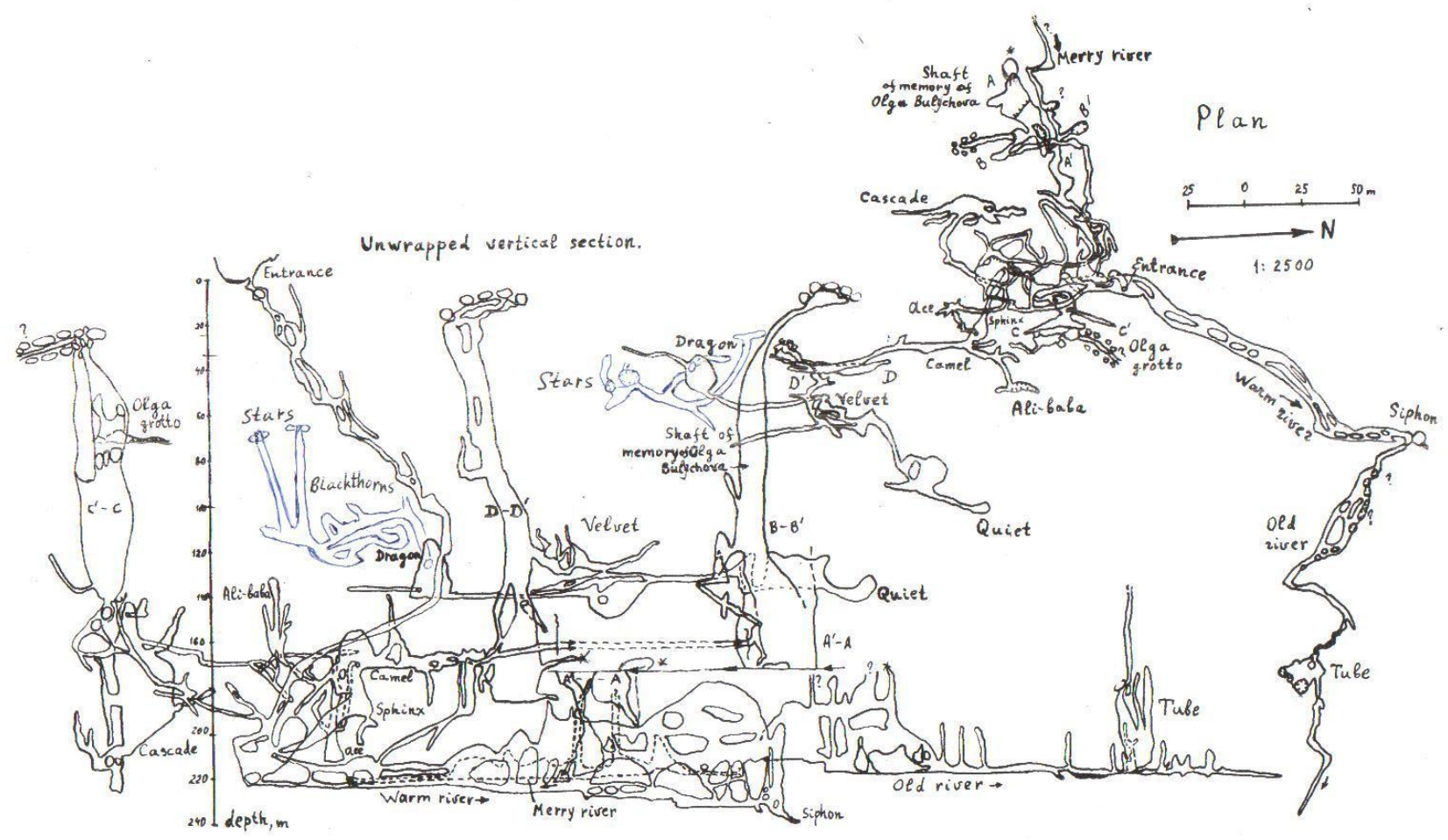

3 TRAINING IN THE FIELD

A. Alpine climbing in caves.

Climbing passion headed us to a new endeavor. Due to tectonic and geophysical investigations (Boulytchov, 2000; Sorokina and Boulytchov, 2001) in caves in Siberia there had to be new systems geographical "white spots" to be discovered. To get there we faced the need to ascend high sheer walls from lower cave levels to upper ones with help of aid alpine techniques since free climbing was insane and it is either impossible to set up protection or because there was not any face-relief. This practice in our club was begun in 1979 and appeared to be one of the first in the world [Серафимов, 2006]. It required a qualitative leap in the training process so far as neither cavers nor sport-climbers taught before this technique. 
Fig.2 Aid climbing technique
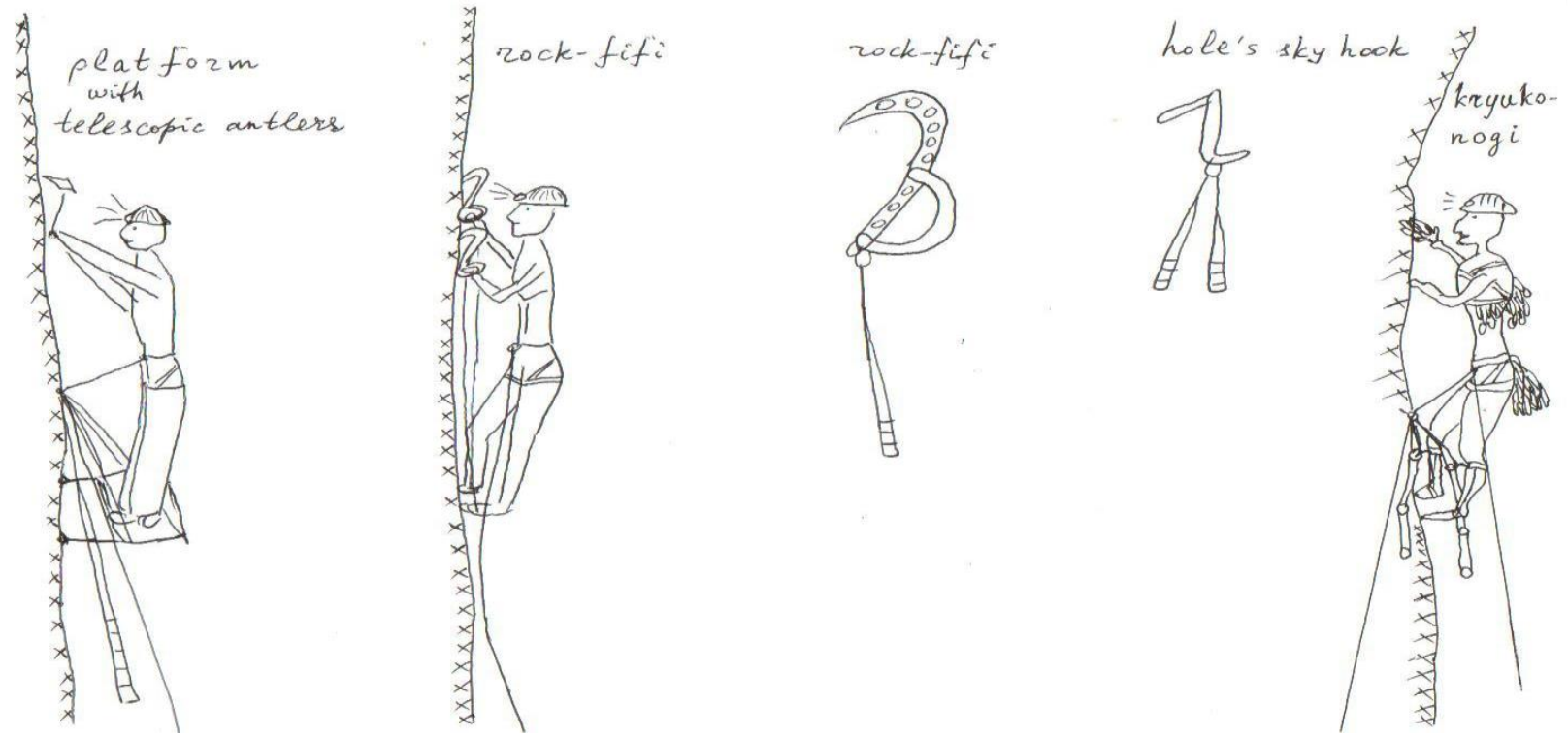

Appreciable discoveries were made in Altaiskaya cave (fig.1), technically the most difficult cave in Siberia with almost $3 \mathrm{~km}$ of vertical sections to ascend and descend. To ascend 40-180m hanging faces (to get upper sub-horizontal storeys) it was mandatory to use storm climbing stairs or kryukonogi (straps with steel rings and steel hooks on stirrups under knees), rock-fifi, hole's sky-hooks (fig.2), telescopic platforms (fig.3), cams, nuts, rurks, pitons, bolts, etc. To perform a complete sport route, a skilled group is required to spend 10 days inside the cave. Compulsory to ascend are shafts Giants (110m), Birthday (170m), named after Olga Bulychova (180m), Tube (70m), 4-th Sump (30m), Sphinx (30m), Red-White (25m), Merry river (several 30m), Old River (several 40m) (fig.4), and "Through blackthorns to the stars" (40m) (Шварц, 2016), etc. 
Fig.3 Climb up with a telescopic platform

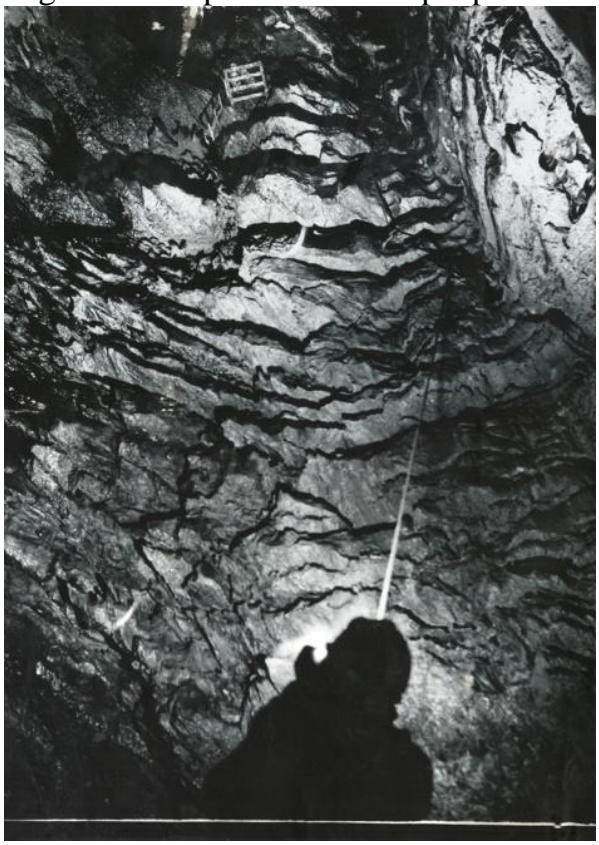

Fig.4 Climb up on Knives Face above Old River B. Alpine mountaineering experience.

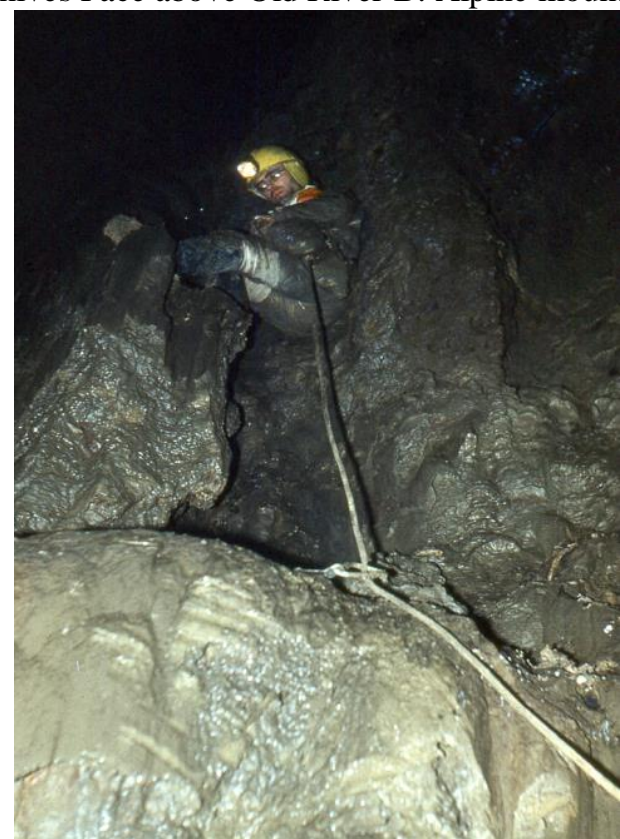

A penchant for climbing has led us to Mount Patroush (fig.5) on the Zeravshanskiy Range (Pasroud valley). The plateau $(100 \times 3000 \mathrm{~m})$ on the top $(4050 \mathrm{~m})$ is elevated $2,2 \mathrm{~km}$ above its water discharge (powerful stream around the base of the mount). Table shaped, cut from all sides by sheer walls, this huge limestone massif required climbing an alpine route of D+ (IY) category (first ascent). The funnel and moat on the plateau are deadly corked by shuttered rocks. A promising cleft was found $100 \mathrm{~m}$ lower on the face but it ended up only so far on $150 \mathrm{~m}$ depth and is too narrow to continue without widening. 


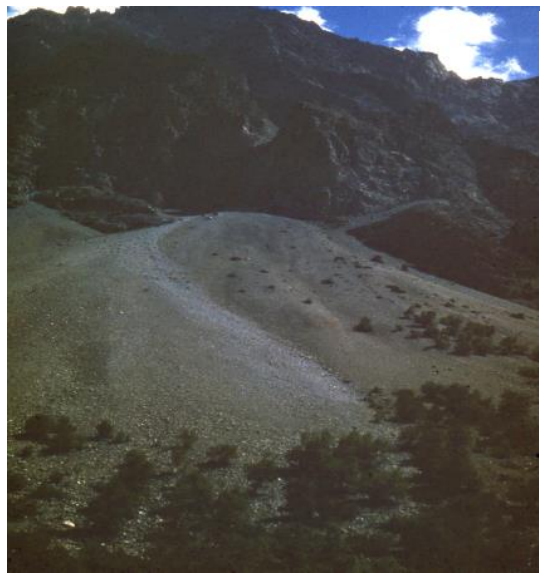

Fig. 5 Mount Patroush Face

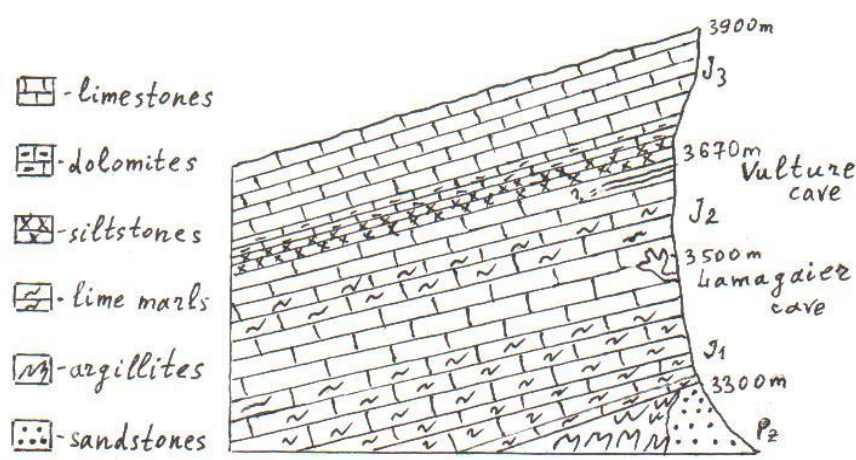

Fig. 6 Cross-section of Hodja-Ahcha-Baroun FaceThe Hodja-Ahcha-Baroun Plateau (Gissarskiy range) is situated not far from famous Hodja-Gurgur-Ata area (where Boi-Boulok cave is laid in) at 3900m altitude with water discharge to Tamerlan cave at 1100m. Mighty layers of carbonate rocks (Mesozoic Jurassic $\mathrm{J}_{1-3}$ ) are interrupted on depths of about $180 \mathrm{~m}$ (fig.6) by dense dolomites and siltstones so all caves previously found here from the surface are blocked at these depths by collapses and mud. The sheer hanging face up to $600 \mathrm{~m}$ high on the flank of folding ridge of the plateau performs a natural cross-section where two holes of possible caves were visible (fig.7). Lamagaier Cave (about 200m up from the base of the wall) was found to be large but blind. Vulture Cave (370m to climb up, fig.8) looks like a fissure with a squeeze passage $(100 \mathrm{~m})$ but it stretches along monoclinal layer lower than the blocking rocks in direction of Tamerlan Cave. The squeeze needs work to widen it, because of its draught. In Tamerlan Cave a series of cascades along a river was aid-climbed up by the team of Tim Guilford (Oxford) heading to the plateau (Зубков, 2000); they ended up on the next shaft up because of time and gear limitations. 
Fig.7 Hodja-Ahcha-Baroun Face

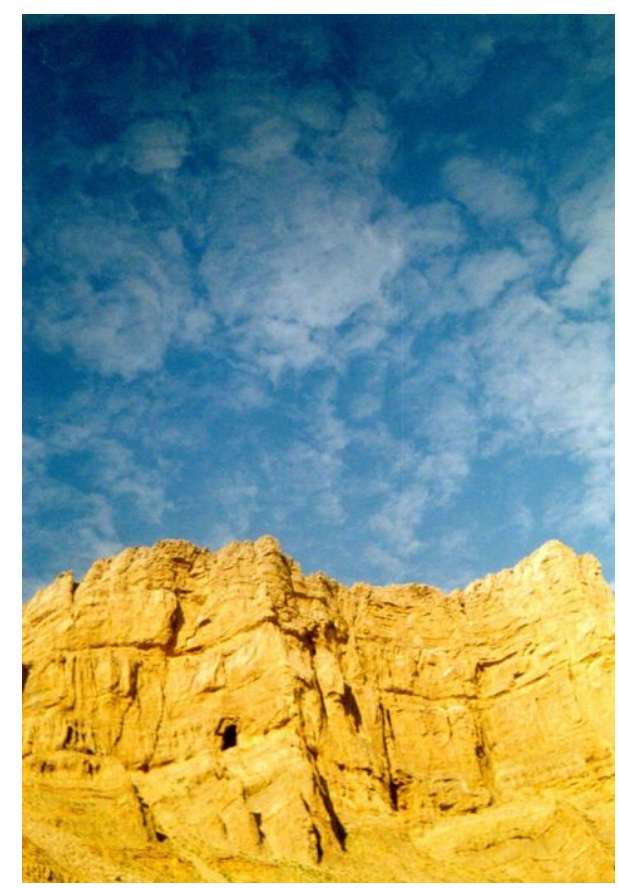

Fig.8 View from Vulture fissureAfter an alpine expedition on Khan-Tengri and Pobeda peaks

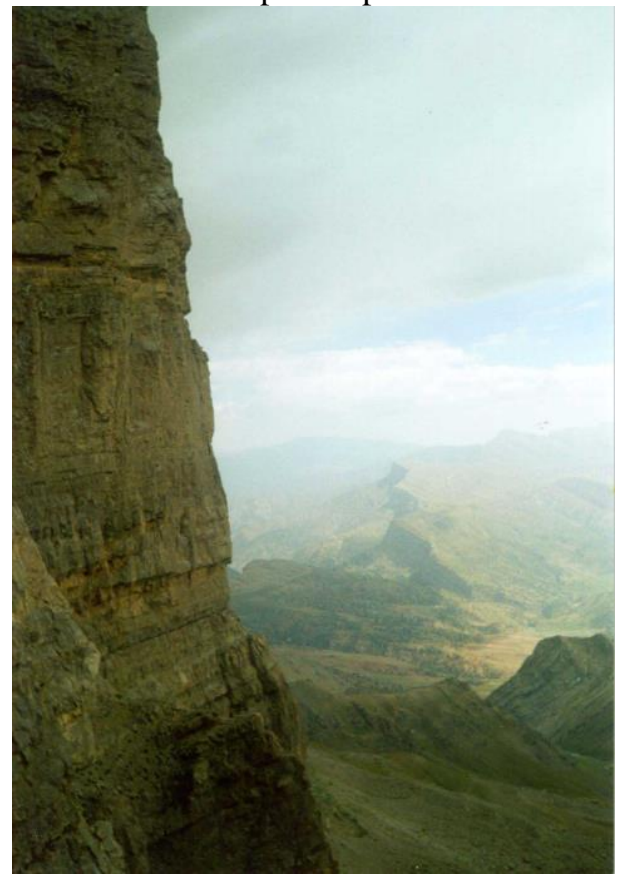

(Kirgizstan) the lake Merzbaher (altitude $3300 \mathrm{~m}$ ) was explored. Water (capacity $0,13 \mathrm{~km}^{3}$ ) from this reservoir (area $2 \mathrm{~km}^{2}$, depth 50-80m) disappears usually once a year (end of August) or occasionally twice (end of October) into 20km of tunnels under Inylchek Glacier totally discharging for 2 days. The lateral moraine of the glacier is a natural dam of the lake with mix of clay, clayey-rubble mass in lower part. This mass when under extra-water pressure (up to 6-8 atmospheres) becomes liquid-saturated 
converting to a thixotropic slurry, the fluidity of which increases like a hydraulic blow removing all material in its way (Головин, 2005). When the water totally disappears from the lake, the fluidity drops to zero, and the suspended clay transforms to pure clay sealing all conduits. In this way the accumulation of water starts again creating new lake.

A similar phenomenon and explanation was surveyed in Kashkulakskaya Cave in Siberia. Water floods this cave occasionally forming a 50m deep big lake that gradually increases for a month (fig.9). Finally all water disappears discharging dartingly into a griffon in the valley.
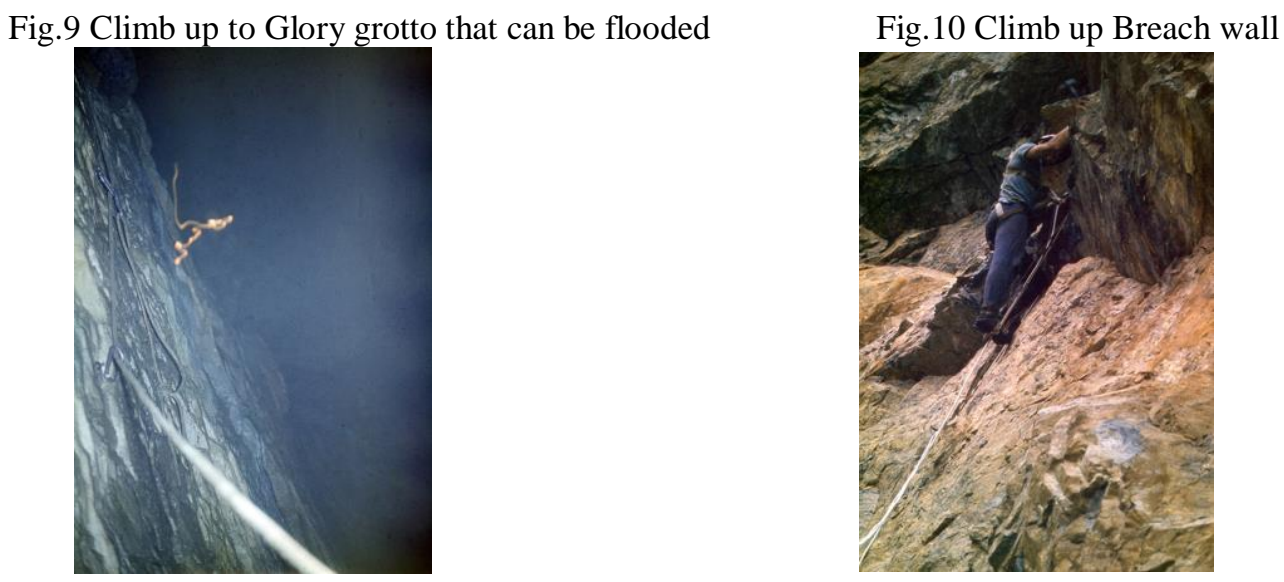

While climbing Kilimanjaro peak on the upper part (about 5000m) of Breach wall (fig.10) a gravitational fissure was observed, ending up at $50 \mathrm{~m}$ (blocked by shuttered rocks).

On descent from Aconcagua peak at an altitude about $6900 \mathrm{~m}$, a niche in rocks was found for overnight stay (Вронская, 2016). This appeared to be a cleft squeezing 80m deep down but we had to escape after the five day ascent of the 3-km South Face due to the tempest and almost no gas or food.

\section{ETHICS}

Relevant to my long-term caving practice two painful ethical moments should be noted. While mapping one has to provide proper information appropriate to measuring devices but not just to imagination. One has not to forget or to deliberately conceal information from previous explorers and always provide references to their papers or corresponding web resources.

Fair play (Huizinga, 1950) in our process is to train but not to loose health and ability to be virile, vigorous. Meanness is thought to jeopardize mates by instigating to rush into doing insane bold exploits for vanity. Opposite, we discourage competition inside the group but aim to help mates since when we are in a cave we are an immediate family. We try to overcome a route not due to a desperate audacity or prevailing upon oneself but according to skills that are being improved by regular trainings. The purpose is to be well-rounded, to feel a balance and serenity on nature and in life. 


\section{CONCLUSION}

Multi-faceted training of cavers resulted in qualitative breakthrough in overcoming of known sporting routes, the discovery of new ones, and in the exploration of new objects either in caves or mountains.

\subsection{TECTONIC-GEOMORPHOLOGIC APPROACH TO STUDY CONGLOMERATE CAVES OF NARVA'S SUITE}

The area of Manskiy trough (East Sayan) represents a part of a large synclinorium. The layer of conglomerates $2000 \mathrm{~m}$ thick belongs to Narva's suite of lower Ordovician and covers $132 \mathrm{~km}^{2}$ but the karst area occupies only $36 \mathrm{~km}^{2}$ (Карст..., 1990).

The rocks correspond to calcareous-dolomitice clays and marls, in which caves are generally not developed, and Narva's conglomerates which contain large cavities, are being considered of karst origin. This is due to the structure of the rock, consisting of debris and cement, where dissolution of any of the components leads to a selective loss of strength. The cement of the rock has a high degree of fracturing, which is exemplified by intensive dripping from dead-end domed tubes. The rock composing boulders is fine-grained and crossed by 2-3 systems of fractures.

The site with the largest caves is subject to tectonic fragmentation. In the caves, there are interlayer fracturings, and a network of faults. The conglomerate layers dip south-west-ward with an inclination from 45 to sometimes $80^{\circ}$. The entrances to the caves are located at an altitude of $600 \mathrm{~m}$, relative elevations are up to $250 \mathrm{~m}$. The relief of the surface is formed by erosion and denudation. Karst is heavily turfed and poorly expressed on insignificant fragments of the flatten surfaces.

The main elements of the cave system are galleries of vaulted and triangular cross-sections 4-15 $\mathrm{m}$ wide, 2-30 $\mathrm{m}$ high, passages and squeezes with blocky and loamy deposits. Isometric rooms sometimes reach more than $30 \mathrm{~m}$ in diameter. Genesis of voids is erosional and tectonic-denudational with accumulation of loam and blocks of debris. Occasionally in the rooms there are snow-white and reddish stalactites, stalagmites, draperies, and cascades. Vertical shafts and chimneys with a depth of 6-40 m, elliptical and slit-shaped, connect the underlying and overlying parts of the cave system.

The main factor of the dynamic system is corrosion due to condensation, infiltration of water and transfer of water vapor, so Badjeiskaya and Big Oreshnaya caves are still developing (new systems and rooms that were either impossible to get into 45 years ago or that were dug open). The presence of calcium bicarbonate in water vapor is evidenced by numerous exudates: spherulites, grains, flowers, and the Crystals Gallery, discovered in 1978, all consist of crystalline sheaf-like aggregates. The number of 
luminescent moon-milk in «Galaxy way» and in «Siberian system» has increased. Moon-milk is probably a white cement of vein calcite with ${ }^{88} \mathrm{Sr}$ impurities (Отложения..., 1985).

Permanent watercourses have little flow rate (up to $3.5 \mathrm{l} / \mathrm{sec}$ ). Most of the streams are cut into loams, but the Porcelain Creek in Badjeiskaya and the streams in the rooms of Dreams, Mazodrom, Adventure, Columnar in Big Oreshnaya are cut into the bedrock. Temporary streams are intensively eroding in vertical cracks. Active infiltration of karst waters is represented by intense dripping.

Permanent small lakes were formed by the clogging of the bottom of rooms or galleries with loam. Large lakes are located at the lower levels of the caves, but their drainage towards the surface was not found.

The deposits are represented by loams, consisting of sandy, silty and clayey particles interspersed with pebbles. The clay mineral is represented by hydromica. The accumulation of loams continues in the passages along their longitudinal axis in the form of swelling.

The morphology of the area shows that Badjeiskaya cave was opened by a nival-corrosive shaft (23 $\mathrm{m}$ deep) and developed initially at the same level (the impressive volumes of the Broadway gallery are about $0.5 \mathrm{~km}$ long), Big Oreshnaya was opened by slope denudation and developed simultaneously at different levels.

\subsection{HISTORY OF SPELEOGENESIS}

Speleogenesis at the initial stage is associated with the formation of a Miocene peneplain (Карст..., 1990) and occurred due to the structural factors of rocks with selective high water permeability.

In the Neogene, the conglomerate was saturated with water. As the neotectonic uplift increased and karst discharge decreased, the water saturation of the speleosystem dwindled. Fluctuations in climatic conditions significantly influenced the formation of karst waters. In the caves, the pluvial of the MiddleUpper Pleistocene can be traced by following the tracks of lake levels and relics of thick drip crusts.

At the contemporary (Late Quaternary) stage of speleogenesis, the leading factor is the complex denudation and development of cave systems along tectonic faults.

From the main entrance, Big Oreshnaya cave is 155 meters deep. The bottom sump is $35 \mathrm{~m}$ deep. The highest point of the cave (system "Zastrem") is situated 44 meters above the main entrance. So the recent amplitude of Big Oreshnaya cave is $234 \mathrm{~m}$. The total volume of voids is estimated to be over $400000 \mathrm{~m}^{3}$. All separate parts and systems of the cave are mapped carefully and appear to be more than $60 \mathrm{~km}$ totally. But it is still difficult to synthetise all of them to a general map (Boulytchov, 1999, fig. 11), so an accomplished map doesn't exist completely yet. Persistent efforts to perform the entire map are being continued. Young cavers have been working a lot last 20 years but mostly digging a loam in narrows 
or excavating in breakdowns, and they have succeeded to discover new systems. But the mapping is hardly being done.

Fig. 11. Preliminary map of Big Oreshnaya cave and deduced faults, along which the cave is developed

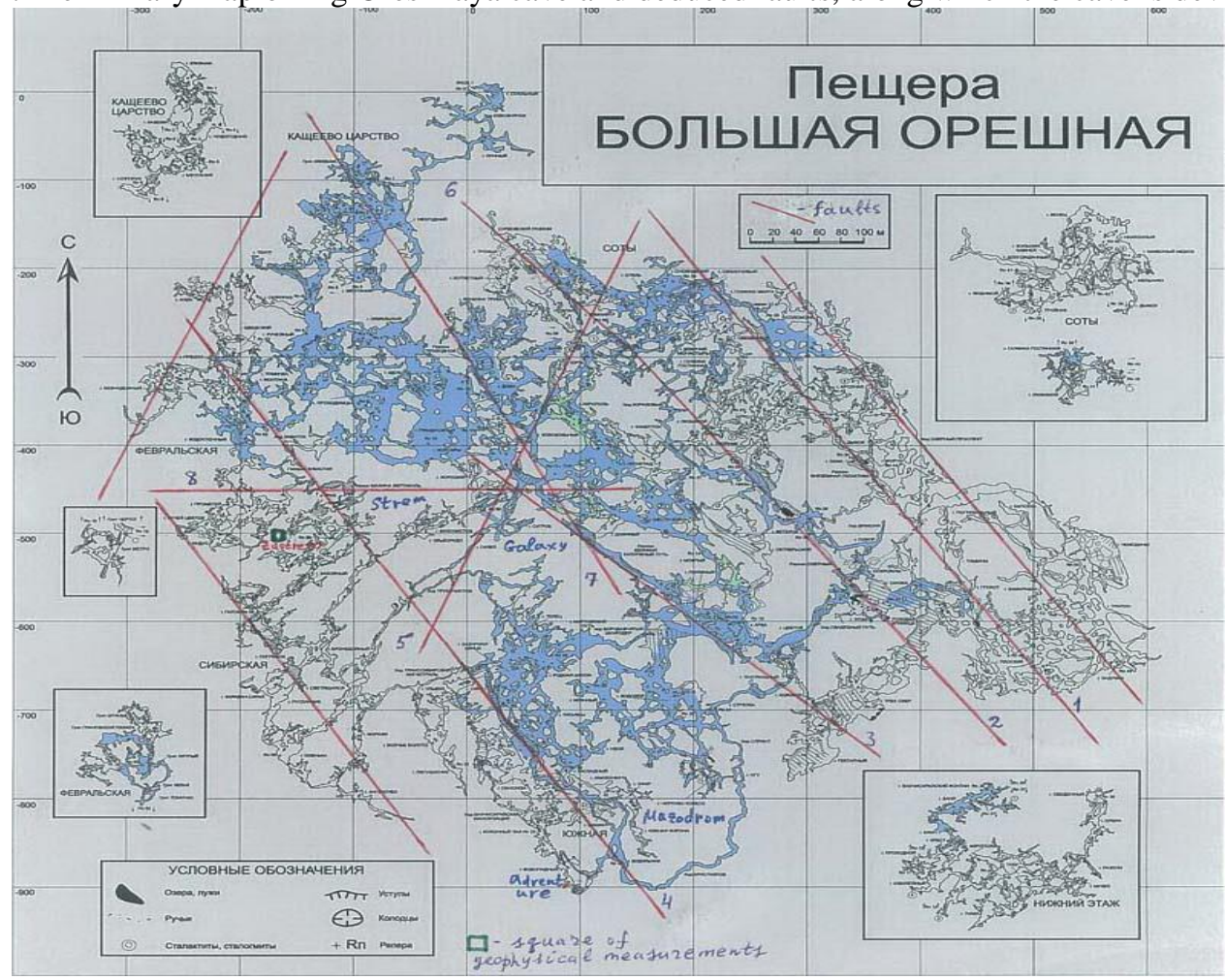

\subsection{DIGITAL IMAGING AND GEOMORPHOLOGIC OBSERVATIONS}

There are up-to-date methods for cave mapping (Kempe, Bauer, 2017; Mitchell, 2017) and surface imaging (Hellstrom, 2017) but they are found to be either too expensive or hard labored. In our measurements the laser (Leica HDS 7000) was applied and on the surface the aerial stereophotografs with consecuitive instrumental treatment were used (Теория..., 1999). The program Survex-Win 32 of Inkscape (Golicz, 2017) for imaging was executed, and extensions .3D, .lox, ashx, png were accepted. According the structural analysis (Теория..., 1999) of the massif in field the parameter of fractural voidness was measured and calculated and occurred to be $0,1-0,3$ what is very high value.

After our discovery of Siberian, Lotos and Strem systems where we had to free climb up $70 \mathrm{~m}$ vertical and overhanging walls (Bulychov, Sorokina, 2013), we proposed to search on the upper part of the mountain where Big Oreshnaya cave is developed. This prompted us to carry out seismic-electrical (Boulytchov, 2000, Bulychov, 2003) measurements on the surface near the top of the mountain on a relatively flat area. As a result of processing the geophysical data, emptinesses were recorded at depths of 3-8 m. It gave enthusiasm to squeeze through a breakdown in the Strem system upwards to discover 
Zastrem system which appeared to be very close to the surface (3-5 m but totally blocked by calcitecemented boulders).

The assumption about the possible continuation of the cave along the upper horizons led to the search for fragments of ancient alignment surfaces near the top of the mountain and in the direction of the significant Rucheinaya cave, which has been very actively extended towards Big Oreshnaya cave the last year. By means of deciphering aerial photographs, signs of destroyed peneplains and faults were deduced (fig. 12).

A similar situation is observed on the massif of Badjeiskaya cave (fig. 13), as a result at the intersection of the faults a completely new Dudinskaya cave was recently discovered (more than $20 \mathrm{~km}$ of passages with chasms and a mesh labyrinth were promptly mapped - gratitude to Artem Barinov, Krasnoyarsk Speleo Club).

Fig.12. Deciphered faults and projection of the map of Big Rucheinaya caves to the surface
Fig.13. Deciphered faults and projection of the map Oreshnaya and of Badjeiskaya and Dudinskaya caves to the surface

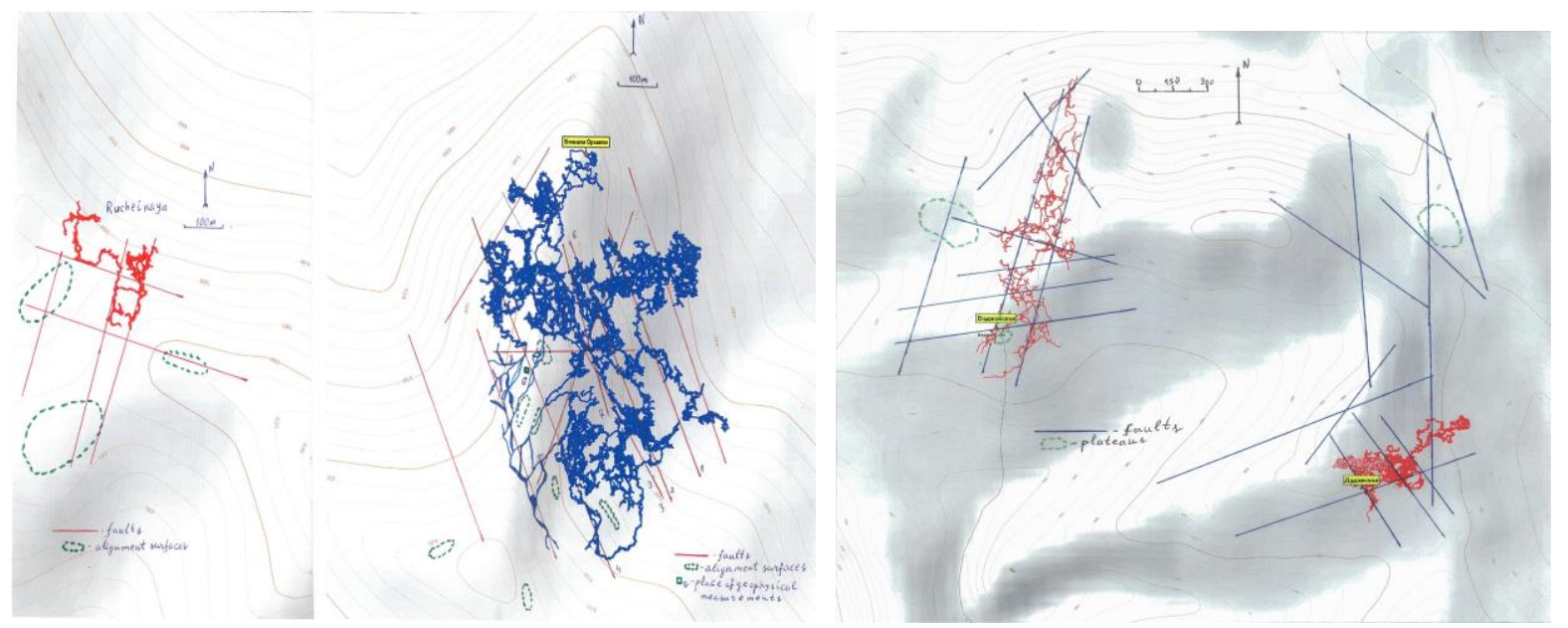

\subsection{DISCUSSION}

It is clearly seen (fig. 12) that Big Oreshnaya cave is developed in a block bound by a network of faults, which is geomorphologically expressed by a sharp bend of the horizontal lines in the massif. Moreover, it was possible to clearly identify faults to the west of the main massif of the cave, along which the cavers have not yet found anything. Since we have already discovered a very significant extension of the cave in the upper part of the Vertical fault, there is reason to try our luck to make new discoveries in the upper parts of other faults. 
The latest tectonic-geomorphologic studies of the massif of Badjeiskaya cave display a vast intact potential of geographic discoveries of underground relief (fig. 13), and it seems to be a very prospective area. The study of the data obtained allowed us to infer the following conclusions:

- perspective for the development of Big Oreshnaya cave along upper levels is quite possible (especially to the West);

- there is a prospect of significant discoveries of the underground world to the North, North-east and South from the cave Dudinskaya, to the North and West from the cave Badjeiskaya.

\section{ACKNOWLEDGEMENTS}

I am faithfully grateful to our fraternity for a human support in life, particularly to close friends: Vladimir Sorokin, Vladimir Chub, Vladimir Shikhov, Aleksandr Lelyak, Aleksey Zdanov, Dmitriy Rogozin, Vasiliy Sherbakov, Petr Minenkov. 


\section{REFERENCES}

Boulytchov A.A. Kektash - the deepest cave of Siberia and Big Oreshnaya - the longest one // Stalactite, Bern, Switzerland, 1999. № 49, 1, pp 47-48.

Bulychov A.A. Seismic-electric effect experiments on shallow subsurface geological cross-section // Exstended abstracts of EAGE, Near surface methods - electromagnetics, Stavanger, Norway, 2003. V.2, P098.

Boulytchov A.A. Seismic-electric effect method on guided and reflected waves // Physics and Chemistry of the Earth, Journal of EGS / Oxford-Amsterdam: Elsevier, 2000. V. 25, № 4, pp 333-336.

Bulychov A., Sorokina T. Club of climbers as a basis for training process of cavers. // Proceedings of the 16th International Congress of Speleology, 2013, V.2, Brno, Czech, pp. 49-51.

Golicz M. Caveink - a set of Inkscape extensions for drawing cave maps // Proceedings of the 17th International Congress of Speleology, Sydney, Australia, 2017. V. 2, pp. 111-115.

Hellstrom, John. Three-dimensional cave mapping using Structure from Motion // Proceedings of the 17th International Congress of Speleology, Sydney, Australia, 2017. V. 2, p. 116.

Huizinga J. Homo Ludens. // L. Brummel, 1950. Amsterdam, Netherlands, pp. 26-246 (in Dutch).

Kempe S., Bauer I. 3-D imaging as a tool to understand speleogenetic processes // Proceedings of the 17th International Congress of Speleology, Sydney, Australia, 2017. V. 2, pp. 117-121.

Mitchell E.J., Mitchell J.N. Comparison of shallow geophysical cave detection methods to 3D Lidar mapping // Proceedings of the 17th International Congress of Speleology, Sydney, Australia, 2017. V. 2, pp. 126-129.

Sorokina T.V., Boulytchov A.A. Seismic-electric benchmarking of shallow subsurface horizons and dome cavities // Proc. Int. Conf. EAGE, 2001, V. 2, Amsterdam, Netherlands, pp. 133-136.

Todhunter A, 1998. Fall of the Phantom Lord. Climbing and the face of fear. In: WSJ, NYC, USA, pp. 130 .

Вронская Е. В поиске смысла. // 2016. https:/www.rgo.ru/ru/article/voshozhdenie-na-pik-akonkaguav-poiske-smysla (in Russian, access 7 Jan 2017).

Головин А. Тайна озера Мерцбахера. // 2005. www.alpclubbars.ru/articles/merzbahera (in Russian, access 7 Jan 2017).

Дублянский В.Н., Илюхин В.В. Путешествия под землёй. 1981. ФиС, Москва (in Russian).

Зубков А. Спелеопоиск Гиссар-2000 // Вертикальный мир, 2000. Москва, 21, с. 15 (in Russian). Карст Сибири / Цыкин Р.А. Красноярск: Изд-во КГУ, 1990. 154 с.

Отложения и полезные ископаемые карста / Цыкин Р.А. Новосибирск: Наука, 1985. 165 с.

Пиратинский AE, 1987. Подготовка скалолаза. ФиС, Москва (in Russian). 
Серафимов К. Техника пещерного стенного лазания. // 2006. www.soumgan.com (in Russian, access 16 Jun 2016).

Ситник М. Основные причины срывов на скалах. // 2016 www.risk.ru/blog/210202 (in Russian, access 7 Jan 2017).

Теория и методология структурно-тектонического анализа в карстоведении. / Катаев В.Н. Пермь: Изд-во ПГУ, 1999. Дис. ... д.Г-м.н. 451 с.

Шварц Д.Б. Пещеры Алтая. // 2016. http://www.nskdiggers.ru (in Russian, access 7 Jan 2017). 